\title{
Source of supplemental dietary copper, zinc, and manganese affects fecal microbial relative abundance in lactating dairy cows
}

\author{
M. J. Faulkner, ${ }^{*}$ B. A. Wenner, ${ }^{* 1}$ L. M. Solden, $\dagger$ and W. P. Weiss ${ }^{* 2}$ \\ *Department of Animal Sciences, Ohio Agricultural Research and Development Center, The Ohio State University, Wooster 44691 \\ †Wrighton Microbiome Laboratory, Department of Microbiology, The Ohio State University, Columbus 43210
}

\begin{abstract}
Appropriate trace mineral supplementation can improve immune response and hoof health in cattle and at much higher rates of supplementation to swine and poultry can alter microbial colonization of the gut, resulting in improved gut health. Diet can influence fecal microbial excretion in cattle, and the fecal microbiome may serve as a means for assessing gastrointestinal microbial changes. We hypothesized that feeding diets that differed in source of supplemental $\mathrm{Cu}, \mathrm{Zn}$, or $\mathrm{Mn}$ would alter the relative abundance of fecal microbes in lactating dairy cattle and that organic $\mathrm{Zn}$ would have the greatest effect. Twenty-four cows were fed diets devoid of supplemental $\mathrm{Cu}, \mathrm{Zn}$, and $\mathrm{Mn}$ for a 16-d preliminary phase (basal diet provided 9, 29, and $32 \mathrm{mg} / \mathrm{kg}$ of $\mathrm{Cu}, \mathrm{Zn}$, and $\mathrm{Mn}$, respectively), and then were randomly assigned to 1 of 3 treatment diets $(n=8$ cows/treatment): one group of cows was fed supplemental $\mathrm{Cu}, \mathrm{Zn}$, and $\mathrm{Mn}$ from sulfate minerals; the second group was fed glycinate minerals; and the third group was fed $\mathrm{Cu}$ and Mn sulfate with glycinate Zn. Assayed total dietary concentrations were approximately 21, 73, and $72 \mathrm{mg} /$ $\mathrm{kg}$ for $\mathrm{Cu}, \mathrm{Zn}$, and $\mathrm{Mn}$, respectively. Milk production (averaged $38.8 \mathrm{~kg} / \mathrm{d}$ ), DMI (averaged $25.8 \mathrm{~kg} / \mathrm{d}$ ), and milk components were not affected by treatment. Fecal DNA was extracted, amplified using a universal primer targeting the V4-V5 hypervariable region of the $16 \mathrm{~S}$ rRNA gene, and sequenced to compare microbial community composition between treatments. Relative abundances of Treponema species-level operational taxonomic units (OTU) were less for animals fed $\mathrm{Cu}$ and Mn sulfate with glycinate $\mathrm{Zn}$ compared with sulfates alone, but were similar to animals fed glycinate mineral sources. Relative abundances for exclusive glycinate mineral and sulfate mineral treatments were similar. Treponema OTU and cultured representatives are of-
\end{abstract}

Received June 28, 2016.

Accepted October 19, 2016.

${ }^{1}$ Current address: Perdue AgriBusiness, Salisbury, MD 21804.

${ }^{2}$ Corresponding author: weiss.6@osu.edu ten associated with bovine digital dermatitis. These data may provide an additional link between organic Zn supplementation and improved hoof health. To our knowledge this is the first report of a dietary treatment decreasing the relative abundance of Treponema OTU in cattle feces; however, the potential benefits of this response on overall animal health and the mechanism for the observed responses are unknown and warrant further investigation.

Key words: fecal microbiome, trace minerals, digital dermatitis

\section{INTRODUCTION}

Pregastric microbiomes in ruminant animals have been studied in great detail and are highly documented (Kim et al., 2011). Although there is still much to learn regarding pregastric microbiomes, even less is known regarding other segments of the bovine gastrointestinal tract. Feeding supplemental trace minerals at dietary concentrations in the 100 to $1,000 \mathrm{~s} \mathrm{mg} / \mathrm{kg}$ range can influence the enteric microbiome populations of poultry (Shao et al., 2014) and swine (Broom et al., 2006). Specifically, Zn supplementation improves gut health and performance in swine (Broom et al., 2006).

Bovine colonic microbes are derived from an accumulation of microbe populations and actions, and fecal samples provide a convenient sample for analyses of these populations (Wells et al., 2014). Fecal bacterial populations can be influenced by diet (Shanks et al., 2011). Supplementation of glycinate minerals has been shown to alter milk fatty acid profiles in lactating dairy cattle (Faulkner, 2016), which may reflect changes in rumen microbial populations. Organic Zn supplementation reduces SCC in lactating dairy cows (Kellogg et al., 2004) and may improve hoof health (SicilianoJones et al., 2008). We hypothesized that feeding diets that differed in source of supplemental $\mathrm{Cu}, \mathrm{Zn}$, or $\mathrm{Mn}$ would alter the relative abundance of fecal microbes in lactating dairy cattle and that organic $\mathrm{Zn}$ would have the greatest effect. Therefore, the objectives of the current study were to (1) determine whether source of supplemental trace minerals fed to lactating dairy 
Table 1. Ingredient composition of the $\operatorname{diet}^{1}(\%$ of DM)

\begin{tabular}{|c|c|c|c|}
\hline Ingredient & Sulfate & Glycinate & Sulfate + glycinate $\mathrm{Zn}$ \\
\hline Corn silage & 27.0 & 27.0 & 27.0 \\
\hline Alfalfa silage & 27.5 & 27.5 & 27.5 \\
\hline Alfalfa hay & 5.0 & 5.0 & 5.0 \\
\hline Ground corn & 20.5 & 20.5 & 20.5 \\
\hline Soybean meal, $48 \% \mathrm{CP}$ & 4.5 & 4.5 & 4.5 \\
\hline Treated soybean meal ${ }^{2}$ & 8.0 & 8.0 & 8.0 \\
\hline Soy hulls & 4.5 & 4.5 & 4.5 \\
\hline Animal/vegetable fat & 0.70 & 0.70 & 0.70 \\
\hline Limestone & 0.81 & 0.81 & 0.81 \\
\hline Dicalcium phosphate & 0.30 & 0.30 & 0.30 \\
\hline Magnesium oxide & 0.07 & 0.07 & 0.07 \\
\hline Iodized salt & 0.52 & 0.52 & 0.52 \\
\hline Selenium premix ${ }^{3}$ & 0.16 & 0.16 & 0.16 \\
\hline Vitamin $\operatorname{mix}^{4}$ & 0.43 & 0.43 & 0.43 \\
\hline $\mathrm{Cu}$ sulfate & 0.00004 & - & 0.00004 \\
\hline Zn sulfate & 0.0001 & - & - \\
\hline Mn sulfate & 0.0001 & - & 0.0001 \\
\hline Glycinate $\mathrm{Cu}^{5}$ & - & 0.00004 & - \\
\hline Glycinate $\mathrm{Zn}^{5}$ & - & 0.0002 & 0.0002 \\
\hline Glycinate $\mathrm{Mn}^{5}$ & - & 0.0002 & - \\
\hline
\end{tabular}

\footnotetext{
${ }^{1}$ The sulfate and glycinate treatments provided all supplemental $\mathrm{Cu}, \mathrm{Zn}$, and $\mathrm{Mn}$ from sulfate or glycinate sources, respectively. The sulfate + glycinate $\mathrm{Zn}$ treatment provided supplemental $\mathrm{Cu}$ and $\mathrm{Mn}$ from sulfate sources and Zn from glycinate.

${ }^{2}$ Aminoplus, Ag Processing Inc., Omaha, NE.

${ }^{3}$ Sodium selenate, $200 \mathrm{mg} / \mathrm{kg}$.

${ }^{4}$ Contained $767 \mathrm{kIU}$ of vitamin A/kg, $279 \mathrm{kIU}$ of vitamin D/kg, 4,900 IU of vitamin E/kg, and $209 \mathrm{mg}$ of biotin (Rovimix Biotin, DSM Nutritional Products, Belvidere, NJ) $/ \mathrm{kg}$.

${ }^{5}$ B-TRAXIM 2C (Pancosma S.A., Geneva, Switzerland). The products contained 270,000, 260,000, and 220,000 $\mathrm{mg}$ of $\mathrm{Cu}, \mathrm{Zn}$, or $\mathrm{Mn} / \mathrm{kg}$, respectively.
}

cattle would alter fecal microbial relative abundance and (2) specifically investigate whether feeding glycinate $\mathrm{Zn}$ combined with $\mathrm{Cu}$ and $\mathrm{Mn}$ sulfate minerals affects fecal microbial relative abundance assessed by $16 \mathrm{~S}$ rRNA gene sequencing differently than all sulfate or all glycinate mineral treatments alone.

\section{MATERIALS AND METHODS}

\section{Cows and Treatments}

All procedures using animals were approved by The Ohio State University Institutional Animal Care and Use Committee.

Twenty-four multiparous Holstein cows $[166 \pm 54$ DIM $( \pm$ SD) at the start of mineral supplementation] were randomly assigned to 1 of 3 dietary treatments (Tables 1 and 2) in a completely randomized design to evaluate the effects of trace mineral source on fecal microbial populations. The experiment lasted $16 \mathrm{~d}$. Prior to the experiment, cows were housed in a common freestall pen and fed the experimental diet, but devoid of supplemental $\mathrm{Cu}, \mathrm{Zn}$, and $\mathrm{Mn}$ (basal diet provided 9,29 , and $32 \mathrm{mg} / \mathrm{kg}$ of $\mathrm{Cu}, \mathrm{Zn}$, and $\mathrm{Mn}$, respectively) for $30 \mathrm{~d}$. This was done to put cows on a similar trace nutrient nutritional plane and to allow previously supplemented trace mineral sources to pass from the gastrointestinal tract. No experimental data were collected during the preliminary phase.

Following the preliminary phase, cows were moved into the tie stall barn and fed a common diet except for changes in trace minerals. Treatments were (1) supplemental $\mathrm{Cu}, \mathrm{Zn}$, and Mn from sulfates; (2) supplemental $\mathrm{Cu}, \mathrm{Zn}$, and $\mathrm{Mn}$ in the glycinate form (B-Traxim, Pancosma, Geneva, Switzerland); or (3) $\mathrm{Cu}$ and $\mathrm{Mn}$ from sulfates with $\mathrm{Zn}$ glycinate. Target total diet $\mathrm{Cu}$, $\mathrm{Zn}$, and Mn concentrations for all treatments were 20, 80 , and $80 \mathrm{mg} / \mathrm{kg}$, respectively. Supplemental minerals were fed daily as a top dress $(0.40 \mathrm{~kg} / \mathrm{d})$.

Diets were fed once daily with a target refusal rate of $2 \%$ of delivered feed and cows were milked twice daily at approximately 0200 and $1400 \mathrm{~h}$ (milk yields were measured electronically). In the tie stalls, individual feed delivery and feed refusal amounts were weighed and recorded daily. Cows were weighed on 2 consecutive mornings (approximately $4 \mathrm{~h}$ after feeding) at the end of the supplementation period.

\section{Feed Samples and Production}

Forages and concentrates were sampled weekly $(\mathrm{n}=$ 2) for future nutrient analysis and weekly dietary DM 
$\left(100^{\circ} \mathrm{C}\right.$ for $\left.24 \mathrm{~h}\right)$ adjustments. A subsample of each top dress mix was sampled immediately following preparation at the feed mill, and an additional sample was taken from each of the individual bags for each treatment when the top dress samples were being weighed out for delivery ( $\mathrm{n}=4$ samples/treatment). All feedstuffs were sent to Cumberland Valley Analytical Services (Hagerstown, MD) for nutrient analysis using wet chemistry methods (AOAC International, 2000). For mineral analyses, samples were ashed $\left(1 \mathrm{~h}\right.$ at $\left.535^{\circ} \mathrm{C}\right)$, digested in $15 \%$ nitric acid, diluted, and assayed by inductively coupled plasma emission spectroscopy. Milk (a.m. and p.m.) was sampled on $\mathrm{d} 7$ of the experimental period and analyzed for milk fat, true protein, lactose (B2000 Infrared Analyzer, Bentley Instruments, Chaska MN), and MUN (Skalar SAN Plus segmented flow analyzer, Skalar Inc., Norcross, GA) by DHI Cooperative Inc. (Columbus, $\mathrm{OH}$ ).

\section{Fecal Sampling and DNA Analyses}

Two fecal grab samples ( $\sim 8 \mathrm{~g} /$ sample) were collected approximately 3 and $9 \mathrm{~h}$ postfeeding from each cow on d 0 (i.e., just before the start of mineral supplementation) and d $16(\mathrm{n}=4$ total collected samples/cow). Samples were collected into separate $15-\mathrm{mL}$ RNaseand DNase-free conical tubes, immediately placed on ice, and frozen at $-80^{\circ} \mathrm{C}$ within $1 \mathrm{~h}$ of sample collection for future analysis. Immediately before fecal sampling, the shoulder length collection sleeves were sprayed with ethanol. New sleeves were used for each cow. Prior to DNA extraction, fecal samples were composited within collection day (d 0 or 16$)$ by weight ( $4 \mathrm{~g} /$ sample). Fecal DNA was extracted (Yu and Morrison, 2004) and nucleic acids were purified before sequencing using the QIAamp DNA Stool Mini Kit protocol (Qiagen Inc., Valencia, CA). Illumina sequencing by MiSeq platform (Illumina Inc., San Diego, CA) was performed by the
Molecular and Cellular Imaging Center (The Ohio State University, Ohio Agricultural and Research and Development Center, Wooster) using reagent kit V3 with $2 \times 300$-bp pair-ended sequencing. The V4-V5 hypervariable region of the $16 \mathrm{~S}$ rRNA gene was targeted with a universal primer and 300-bp pair-ended approach (Caporaso et al., 2010). Data processing was performed using QIIME 1.9.0 (Caporaso et al., 2010). The specific processing steps were as follows. Raw FASTQ data were demultiplexed and quality filtered to a Phred score of 20 , with a minimum sequence length of $200 \mathrm{nts}$, with a total of 733,710 high-quality reads. Operational taxonomic units (OTU) were chosen in a 2-step process. First, sequences were clustered into OTU at $97 \%$ similarity using UCLUST followed by de novo OTU picking, then assigned taxonomy using the 97_SILVA_111 rep set (v123, http://www.arb-silva. de/; Edgar, 2013; Quast et al., 2013). Phyla-, family-, and genus-level operational taxonomic units below $0.5 \%$ relative abundance were not reported here to condense results. The OTU table was analyzed for $\alpha$ and $\beta$ diversity (Shannon-Weiner and Bray-Curtis dissimilarity, respectively) using $\mathrm{R}$ (package vegan, http://cran.rproject.org/web/packages/vegan/).

\section{Statistical Analysis}

Production data and DMI were analyzed using PROC MIXED of SAS (v9.3, SAS Institute Inc., Cary, NC). The model included the fixed effects of treatment (2 df) and residual error. Relative abundance data were analyzed by analysis of covariance using $\mathrm{d} 0$ fecal relative microbial relative abundance as a covariate for d 16 data. The model included the fixed effects of treatment $(2 \mathrm{df})$ and $\mathrm{d} 0$ covariate $(1 \mathrm{df})$, and residual error. Mean separation of significant effects was performed using the PDIFF option in SAS. Relative abundance data were not normally distributed. Data transformations $\left(\log _{10}\right.$,

Table 2. Nutrient composition of the basal diet and feedstuffs ${ }^{1}$

\begin{tabular}{|c|c|c|c|c|c|}
\hline Item & Basal diet & Corn silage & Alfalfa silage & Alfalfa hay & Concentrate \\
\hline DM, \% & 59.3 & 30.0 & 38.3 & 89.8 & 89.1 \\
\hline $\mathrm{NDF}, \%$ & 32.9 & 40.8 & 44.8 & 54.8 & 17.3 \\
\hline Starch, \% & 24.1 & 31.7 & 0.6 & 0.3 & 37.3 \\
\hline CP, \% & 17.3 & 6.7 & 20.9 & 19.2 & 21.3 \\
\hline $\mathrm{Ca}, \%$ & 1.0 & 0.26 & 1.20 & 1.36 & 1.38 \\
\hline $\mathrm{P}, \%$ & 0.4 & 0.25 & 0.33 & 0.30 & 0.56 \\
\hline $\mathrm{Mg}, \%$ & 0.3 & 0.15 & 0.26 & 0.21 & 0.31 \\
\hline $\mathrm{K}, \%$ & 1.9 & 1.35 & 3.11 & 3.19 & 1.20 \\
\hline $\mathrm{Fe}, \mathrm{mg} / \mathrm{kg}$ & 237 & 113 & 390 & 290 & 213 \\
\hline $\mathrm{Cu}, \mathrm{mg} / \mathrm{kg}$ & $9(21)^{2}$ & 7 & 13 & 11 & 9 \\
\hline $\mathrm{Zn}, \mathrm{mg} / \mathrm{kg}$ & $29(73)$ & 19 & 30 & 27 & 29 \\
\hline $\mathrm{Mn}, \mathrm{mg} / \mathrm{kg}$ & $32(55)$ & 27 & 49 & 26 & 32 \\
\hline
\end{tabular}


ARCSIN, and LOGIT) were performed and the results were compared with those of nontransformed data. Data transformation decreased standard errors, but did not influence the occurrence of statistically significant $(P \leq 0.10)$ observations. Therefore, data are presented as relative abundance without transformation.

\section{RESULTS}

Body weight and production measures were similar $(P$ $\geq 0.14$ ) between all treatments (Table 3). Sequencing results returned an average of 1,590 OTU per sample. No difference was detected between treatments for richness $(1,570,1,440$, and 1,490) or Shannon-Weiner index $(5.64,5.21$, and 5.44$)$ for sulfate, sulfate with glycinate, and glycinate mineral treatments, respectively. BrayCurtis dissimilarity, expressed in a nonmetric multidimensional scaling plot (not shown), did not significantly cluster by treatment $(P>0.10)$. The DNA sequencing analysis identified 14 different phyla in the fecal samples, which is greater than previous observations (Mao et al., 2012). Bacteroidetes, Firmicutes, Proteobacteria, Spirochaetes, and Actinobacteria comprised the largest populations of phyla observed in feces (Figure 1) similar to previous observations in dairy cattle (Mao et al., 2012), beef cattle (Shanks et al., 2011), and other mammalian species (Ley et al., 2008). Trace mineral treatment had no effect $(P \geq 0.14)$ on phyla (Table 4$)$ and family (Table 5) fecal microbial relative abundance with the exception of bacteria in phylum Spirochaetes $(P=0.08)$ and family Spirochaetaceae $(P=0.08)$.

Fecal relative abundance of Spirochaetes was similar between treatments before trace mineral supplementation (Supplemental Table S1; https://doi.org/10.3168/ jds.2016-11680). Spirochaetes relative abundance was less for cattle fed $\mathrm{Cu}$ and $\mathrm{Mn}$ sulfate with glycinate $\mathrm{Zn}$ compared with cows fed sulfate minerals $(P=0.03)$, but was similar $(P=0.14)$ to cows fed glycinate minerals only (Table 5). Spirochaetes fecal relative abundance was similar $(P=0.15)$ between cows consuming exclusively glycinate and sulfate mineral sources (Table 5). Spirochaetaceae was the only family identified within the Spirochaetes phylum; therefore, treatment means and differences were the same at the phyla and family level (Tables 4 and 5). Similar to Spirochaetes and Spirochaetaceae, relative abundance for the genus Treponema within Spirochaetaceae was less for cows consuming $\mathrm{Cu}$ and $\mathrm{Mn}$ sulfate with glycinate $\mathrm{Zn}(P=$ 0.03), than for those fed exclusively sulfate minerals, but was similar $(P=0.22)$ to cows fed exclusively glycinate minerals (Figure 2). Six Treponema OTU were identified at low relative abundance (average $=0.3 \%, 5$ uncultured and Treponema zioleckii), but none were different between treatments (data not shown, $P>0.10$ ).

\section{DISCUSSION}

All mineral treatments were fed to modestly exceed (approximately $2 \times \mathrm{Cu}$ and $\mathrm{Zn}$ ) $\mathrm{Cu}, \mathrm{Zn}$, and $\mathrm{Mn}$ requirements (NRC, 2001). Absorption coefficients for glycinate minerals are unknown; therefore, the absorption coefficient values for $\mathrm{Cu}(0.05)$ and $\mathrm{Zn}(0.20$; NRC, 2001) were assumed to be similar between mineral sources, which may or may not be true. Manganese supplied in excess of the NRC (2001) requirement was not calculated because the Mn requirement is underestimated (Weiss and Socha, 2005; Hansen et al., 2006). Target dietary concentrations for $\mathrm{Cu}, \mathrm{Zn}$, and $\mathrm{Mn}$ were 20, 80 , and $80 \mathrm{mg} / \mathrm{kg}$, respectively. Target concentrations were chosen with the intent of supplying equal concentrations of $\mathrm{Cu}, \mathrm{Zn}$, and $\mathrm{Mn}$ from the basal diet and supplemental minerals (Table 2). Supplemental $\mathrm{Cu}$, $\mathrm{Zn}$, and Mn provided approximately 57, 60, and 55\% of total dietary mineral concentrations, respectively, for the mineral treatments.

The effects of source of trace mineral supplementation on production measures are inconsistent (Rabiee et al., 2010) and were not primary objectives in the current study. These data are presented as a means to characterize the cows in the current study.

Table 3. Effects of mineral treatment on production

\begin{tabular}{|c|c|c|c|c|c|}
\hline \multirow[b]{2}{*}{ Item } & \multicolumn{3}{|c|}{ Treatment $^{1}$} & \multirow[b]{2}{*}{ SEM } & \multirow{2}{*}{$\frac{P \text {-value }}{\text { Treatment }}$} \\
\hline & Sulfate & Glycinate & Sulfate + glycinate $\mathrm{Zn}$ & & \\
\hline $\mathrm{BW}, \mathrm{kg}$ & 721 & 730 & 732 & 18.7 & 0.90 \\
\hline DMI, $\mathrm{kg} / \mathrm{d}$ & 25.5 & 25.7 & 26.2 & 0.88 & 0.85 \\
\hline Milk, $\mathrm{kg} / \mathrm{d}$ & 40.3 & 37.3 & 38.8 & 2.30 & 0.66 \\
\hline Milk fat, \% & 3.31 & 3.53 & 3.75 & 0.15 & 0.14 \\
\hline Milk protein, \% & 2.85 & 2.95 & 3.01 & 0.09 & 0.48 \\
\hline Milk lactose, \% & 4.82 & 4.72 & 4.84 & 0.04 & 0.15 \\
\hline
\end{tabular}

${ }^{1}$ Sulfate and glycinate treatments provided all supplemental $\mathrm{Cu}, \mathrm{Zn}$, and $\mathrm{Mn}$ from sulfate or glycinate sources, respectively. The sulfate + glycinate $\mathrm{Zn}$ treatment provided supplemental $\mathrm{Cu}$ and $\mathrm{Mn}$ from sulfate sources and Zn from glycinate. 
Table 4. Effects of feeding different $\mathrm{Cu}, \mathrm{Zn}$, and $\mathrm{Mn}$ treatments on microbial phyla relative abundance (in excess of $0.5 \%$ ) in feces from lactating dairy cows (covariate adjusted using d 0 abundance)

\begin{tabular}{lccccc}
\hline & \multicolumn{2}{c}{ Treatment $^{1}$} & \multicolumn{2}{c}{$P$-value } \\
\cline { 2 - 5 } Item & Sulfate & Glycinate & Sulfate + glycinate Zn & SEM & \multirow{2}{*}{ Treatment } \\
\cline { 2 - 5 } Bacteroidetes & 47.77 & 43.25 & 45.24 & 4.30 & 0.75 \\
Firmicutes & 42.40 & 48.47 & 42.18 & 5.25 & 0.61 \\
Proteobacteria & 1.81 & 0.92 & 5.83 & 1.82 & 0.14 \\
Spirochaetes & $3.16^{\mathrm{a}}$ & $2.21^{\text {ab }}$ & $0.78^{\mathrm{b}}$ & 0.74 & 0.08 \\
Actinobacteria & 0.87 & 1.36 & 1.60 & 0.50 & 0.58 \\
Unassigned & 1.44 & 1.38 & 1.71 & 0.14 & 0.21 \\
Tenericutes & 0.74 & 0.74 & 0.57 & 0.10 & 0.40 \\
Euryarchaeota & 0.73 & 0.59 & 0.85 & 0.27 & 0.77 \\
Fibrobacteres & 0.59 & 0.13 & 0.34 & 0.29 & 0.50 \\
Candidate division TM7 & 0.21 & 0.17 & 0.12 & 0.04 & 0.37 \\
Cyanobacteria & 0.19 & 0.08 & 0.07 & 0.03 & 0.60 \\
Lentisphaerae & 0.08 & 0.07 & 0.12 & 0.98 \\
Verrucomicrobia & 0.06 & 0.18 & 0.05 & 0.05 & 0.21 \\
Candidate division SR1 & 0.04 & $<0.01$ & & 0.27 \\
\hline
\end{tabular}

a,b Means within a row differ $(P<0.05)$

${ }^{1}$ Sulfate and glycinate treatments provided all supplemental $\mathrm{Cu}, \mathrm{Zn}$, and $\mathrm{Mn}$ from sulfate or glycinate sources, respectively. The sulfate + glycinate $\mathrm{Zn}$ treatment provided supplemental $\mathrm{Cu}$ and $\mathrm{Mn}$ from sulfate sources and Zn from glycinate.

\section{Fecal Microbial Phyla}

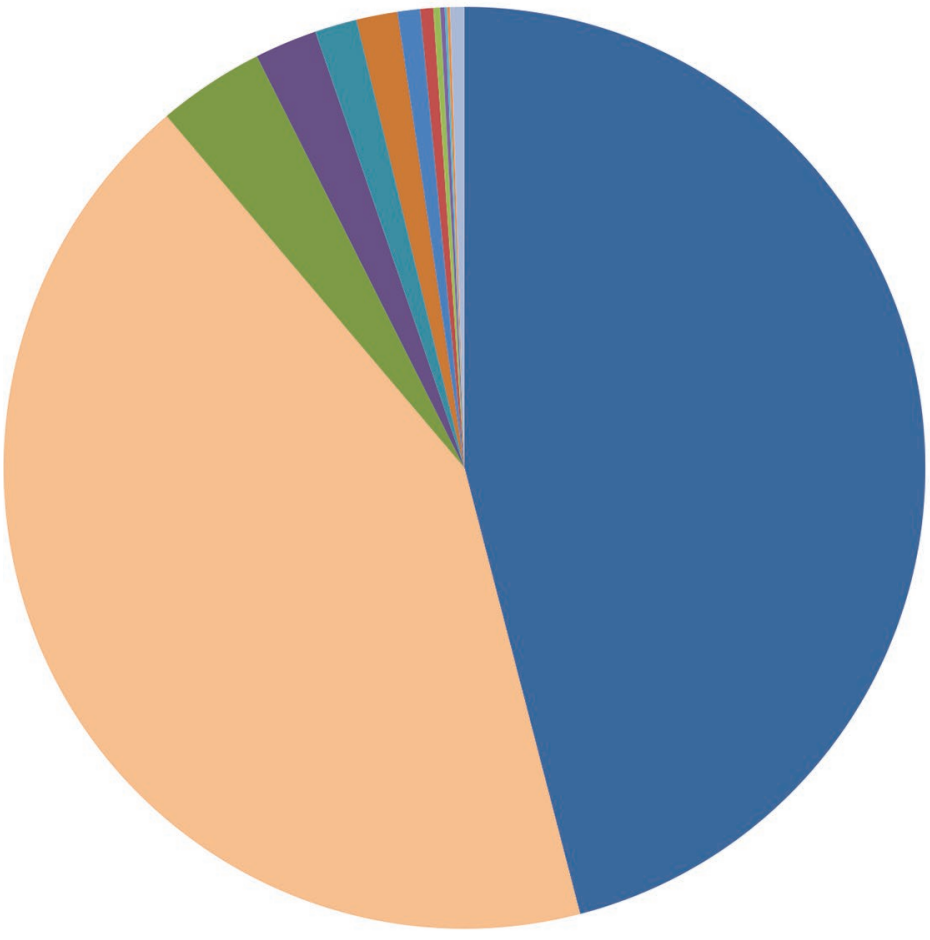

Bacteroidetes 45.8\%

Firmicutes $42.7 \%$

Proteobacteria 3.7\%

- Spirochaetes $2.2 \%$

Actinobacteria 1.5\%

Unassigned 1.4\%

Tenericutes $\mathbf{0 . 8 \%}$

- Fibrobacteres $0.4 \%$

Candidate Division

TM7 0.2\%

Cyanobacteria 0.1\%

Lentisphaerae $0.1 \%$

Verrucomicrobia $0.1 \%$

Euryarchaota $0.5 \%$

Candidate Division SR1 $<0.01 \%$

Figure 1. Average (across treatments) fecal microbial phyla relative abundance in excess of $0.5 \%$ relative abundance for lactating dairy cattle fed no supplemental $\mathrm{Cu}, \mathrm{Zn}$, or $\mathrm{Mn}$ and then fed supplemental $\mathrm{Cu}, \mathrm{Zn}$, and $\mathrm{Mn}$ for $16 \mathrm{~d}$. Color version available online. 
Table 5. Effects of feeding different $\mathrm{Cu}, \mathrm{Zn}$, and Mn treatments on bacterial family relative abundance (in excess of $0.5 \%$ ) in feces from lactating dairy cows (covariate-adjusted using d 0 abundance)

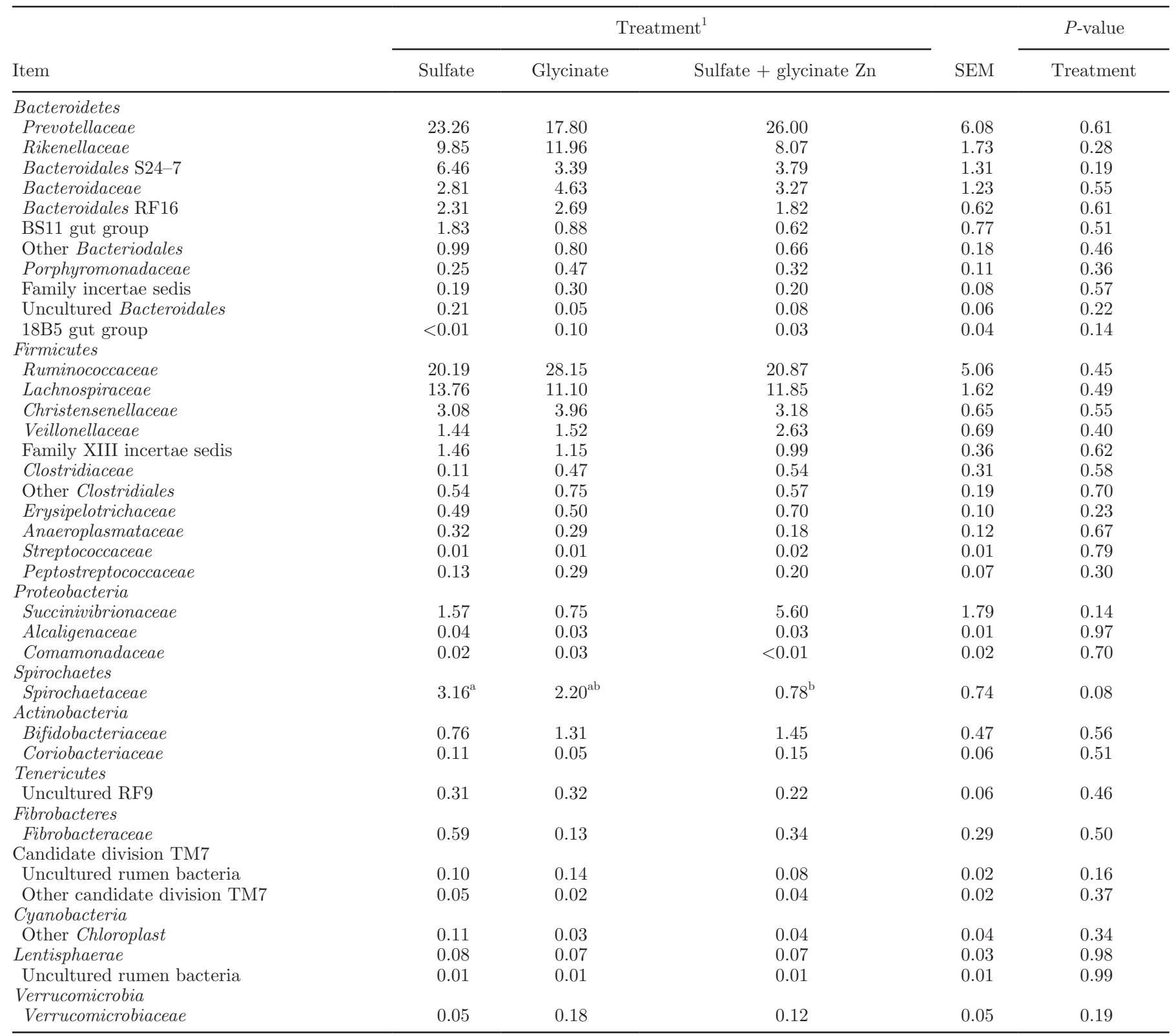

$\overline{\mathrm{a}, \mathrm{b}}$ Means within a row differ $(P<0.05)$.

${ }^{1}$ Sulfate and glycinate treatments provided all supplemental $\mathrm{Cu}, \mathrm{Zn}$, and $\mathrm{Mn}$ from sulfate or glycinate sources, respectively. The sulfate + glycinate $\mathrm{Zn}$ treatment provided supplemental $\mathrm{Cu}$ and $\mathrm{Mn}$ from sulfate sources and $\mathrm{Zn}$ from glycinate.

Spirochaetaceae are free-living or host-associated, obligate, or anaerobic spiral-shaped bacteria that have high motility (Karami et al., 2014). Spirochaetes such as Treponema are unique because they have a rapidly rotating axial flagellum that allows them to move freely and invade and colonize host tissues, and are known to cause diseases such as Lyme disease and syphilis (Karami et al., 2014). In cattle, Treponema bacteria have been associated with bovine digital dermatitis
(Brandt et al., 2011; Evans et al., 2011, 2012). Amplified Treponema DNA strains $T$. pedis sp. Nov., $T$. medium ssp. bovis, and T. phagedenis ssp. vaccae were identified in 51.0, 37.7, and 4.4\% of skin lesions in dairy cows diagnosed with bovine digital dermatitis (Brandt et al., 2011). Treponema species associated with bovine digital dermatitis have been observed in the rumen, feces, slurry, and skin lesions (Klitgaard et al., 2014; Zinicola et al., 2015) and may be transferred by touch 


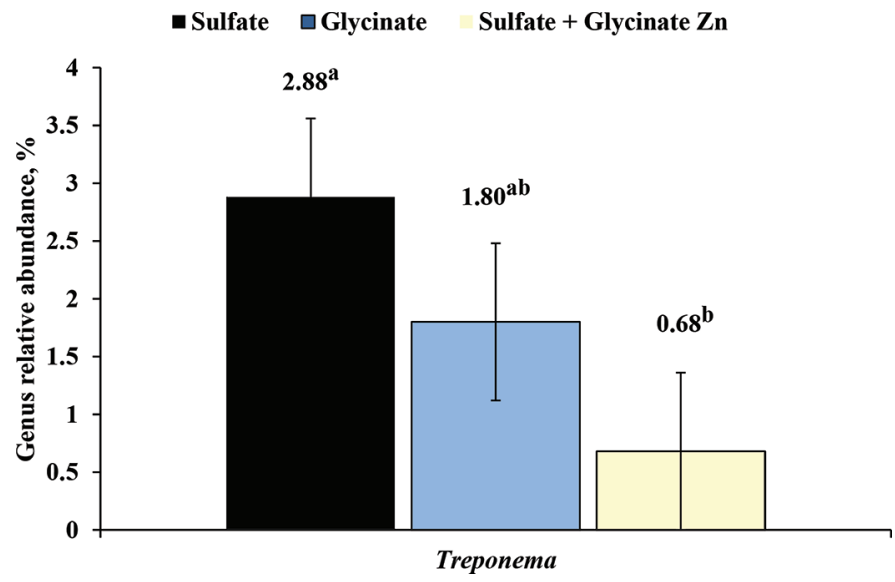

Figure 2. Treatment effects $(P=0.10)$ on fecal Treponema relative abundance (in excess of $0.5 \%$ ) in lactating dairy cows fed supplemental minerals for $16 \mathrm{~d}$ (covariate-adjusted using d 0 abundance). Sulfate and glycinate treatments provided all supplemental $\mathrm{Cu}, \mathrm{Zn}$, and $\mathrm{Mn}$ from sulfate or glycinate sources, respectively. The sulfate + glycinate $\mathrm{Zn}$ treatment provided supplemental $\mathrm{Cu}$ and $\mathrm{Mn}$ from sulfate sources and $\mathrm{Zn}$ from glycinate. ${ }^{\mathrm{a}, \mathrm{b}}$ Mean relative abundance differs $(P<0.05)$ between treatments. Error bars represent SEM. Color version available online.

(Evans et al., 2012). The bovine gut has been suggested to be a primary reservoir of bacteria related to digital dermatitis (Zinicola et al., 2015).

Increased keratinization in response to feeding supplemental Zn (Moore et al., 1989; Kessler et al., 2003), as well as other trace nutrients (Tomlinson et al., 2004), has long been the suspected mechanism for trace nutrients improving hoof health. Data from our experiment suggest an additional mode of action. Zinc glycinate may improve hoof health by reducing hoof exposure to the Treponema bacterial species associated with bovine digital dermatitis via reduced fecal excretion of the bacteria.

Zinc is an essential nutrient to bacterial metabolism and increases extracellular stability when bound to the exterior bacterial cell wall (Durand and Kawashima, 1980). Campylobacter jejuni, a commensal bacterium in chickens, is unable to replicate or colonize in the gastrointestinal tract when the bacteria is lacking $\mathrm{Zn}$ transporter ZnuA (Gielda and DiRita, 2012). Extremely high Zn $(3,100 \mathrm{mg} / \mathrm{kg})$ supplementation from Zn oxide to weanling pigs increased intestinal $\operatorname{IgA}$ and reduced mesenteric lymph nodes, possibly by altering cytokine profiles in gut-associated lymphatic tissue, and neutralization of bacteria (Broom et al., 2006).

The mechanism of action for the observed treatment differences in bacterial fecal relative abundance is unclear. Why cows fed $\mathrm{Cu}$ and $\mathrm{Mn}$ from sulfates with organic $\mathrm{Zn}$ had less fecal relative abundance of Spirochaetes bacteria compared with the all glycinate treatment is also unclear. Copper can be toxic to rumen bacteria (Durand and Kawashima, 1980) and $\mathrm{Cu}$ sulfate footbaths are used on dairy farms to treat hoof disease. Increased concentrations of soluble, reduced $\mathrm{Cu}$ may have been present in the intestine when $\mathrm{Cu}$ sulfate was fed compared with glycinate $\mathrm{Cu}$, and these effects combined with $\mathrm{Zn}$ glycinate provided the optimal environment to reduce fecal abundance of Spirochaetes bacteria. Further experimentation is needed to elucidate the mode of action. However, no intestinal observations were made, and fecal excretion of bacteria may not mimic intestinal abundance.

\section{CONCLUSIONS}

Feeding $\mathrm{Cu}$ and $\mathrm{Mn}$ sulfate with $\mathrm{Zn}$ glycinate at modest supplemental concentrations decreased fecal relative abundance of Treponema spp. within phylum Spirochaetes. Treponema spp. have been associated with the occurrence of bovine digital dermatitis, and decreasing excretion may improve hoof health. The mechanisms of action for reduced relative abundance, why the combination of mineral sources had the greatest response compared with exclusively sulfate or glycinate sources, or if less excretion of the bacteria species means less colonization are unclear. However, this study identified a new potential mode of action for the positive effects organic Zn can have on bovine digital dermatitis. Further investigation into the health effects and mechanism of action of these observations is warranted.

\section{ACKNOWLEDGMENTS}

Research was supported by state and federal funds appropriated to The Ohio State University. Additional funds were provided by Pancosma S.A., Geneva, Switzerland.

\section{REFERENCES}

AOAC International. 2000. Official Methods of Analysis. Vol. 1 and 2. 17 ed. AOAC International, Gaithersburg, MD.

Brandt, S., V. Apprich, V. Hackl, R. Tober, M. Danzer, C. Kainzbauer, C. Gabriel, C. Stanek, and J. Kofler. 2011. Prevalence of bovine papillomavirus and treponema DNA in bovine digital dermatitis lesions. Vet. Microbiol. 148:161-167.

Broom, L. J., H. M. Miller, K. G. Kerr, and J. S. Knapp. 2006. Effects of zinc oxide and Enterococcus faecium SF68 dietary supplementation on the performance, intestinal microbiota and immune status of weaned piglets. Res. Vet. Sci. 80:45-54.

Caporaso, J. G., J. Kuczynski, J. Stombaugh, K. Bittinger, F. D. Bushman, E. K. Costello, N. Fierer, A. G. Pena, J. K. Goodrich, J. I. Gordon, G. A. Huttley, S. T. Kelley, D. Knights, J. E. Koenig, R. E. Ley, C. A. Lozupone, D. McDonald, B. D. Muegge, M. Pirrung, J. Reeder, J. R. Sevinsky, P. J. Turnbaugh, W. A. Walters, J. Widmann, T. Yatsunenko, J. Zaneveld, and R. Knight. 2010. 
QIIME allows analysis of high-throughput community sequencing data. Nat. Methods 7:335-336.

Durand, M., and R. Kawashima. 1980. Influence of minerals in rumen microbial digestion. Pages 375-408 in Digestive Physiology and Metabolism in Ruminants. Y. Ruckebisch and P. Thivend, ed. Avi Publ. Co., New York, NY.

Edgar, R. C. 2013. UPARSE: Highly accurate OTU sequences from microbial amplicon reads. Nat. Methods 10:996-998.

Evans, N. J., J. M. Brown, R. D. Murray, B. Getty, R. J. Birtles, C. A. Hart, and S. D. Carter. 2011. Characterization of novel bovine gastrointestinal tract treponema isolates and comparison with bovine digital dermatitis treponemes. Appl. Environ. Microbiol. $77: 138-147$.

Evans, N. J., D. Timofte, D. R. Isherwood, J. M. Brown, J. M. Williams, K. Sherlock, M. J. Lehane, R. D. Murray, R. J. Birtles, C. Anthony Hart, and S. D. Carter. 2012. Host and environmental reservoirs of infection for bovine digital dermatitis treponemes. Vet. Microbiol. 156:102-109.

Faulkner, M. J. 2016. Effects of trace mineral supplementation in lactating dairy cows. PhD Diss. Dept. of Animal Sciences, Ohio State Univ., Columbus.

Gielda, L. M., and V. J. DiRita. 2012. Zinc competition among the intestinal microbiota. MBio 3:e00171.

Hansen, S. L., J. W. Spears, K. E. Lloyd, and C. S. Whisnant. 2006 Feeding a low manganese diet to heifers during gestation impairs fetal growth and development. J. Dairy Sci. 89:4305-4311.

Karami, A., M. Sarshar, R. Ranjbar, and R. S. Zanjani. 2014. The phylum spirochaetaceae. Pages 915-929 in The Prokaryotes. Springer, New York, NY.

Kellogg, D. W., D. J. Tomlinson, M. T. Socha, and A. B. Johnson. 2004. Effects of zinc methionine complex on milk production and somatic cell count of dairy cows: Twelve-trial summary. Prof. Anim. Sci. 20:295-301.

Kessler, J., I. Morel, P. A. Dufey, A. Gutzwiller, A. Stern, and H. Geyer. 2003. Effect of organic zinc sources on performance, zinc status and carcass, meat and claw quality in fattening bulls. Livest. Prod. Sci. 81:161-171.

Kim, M., M. Morrison, and Z. Yu. 2011. Status of the phylogenetic diversity census of ruminal microbiomes. FEMS Microbiol. Ecol. $76: 49-63$.

Klitgaard, K., M. W. Nielsen, H. C. Ingerslev, M. Boye, and T. K. Jensen. 2014. Discovery of bovine digital dermatitis-associated treponema spp. in the dairy herd environment by a targeted deepsequencing approach. Appl. Environ. Microbiol. 80:4427-4432.

Ley, R. E., M. Hamady, C. Lozupone, P. J. Turnbaugh, R. R. Ramey, J. S. Bircher, M. L. Schlegel, T. A. Tucker, M. D. Schrenzel, and R. Knight. 2008. Evolution of mammals and their gut microbes. Science 320:1647-1651.
Mao, S., R. Zhang, D. Wang, and W. Zhu. 2012. The diversity of the fecal bacterial community and its relationship with the concentration of volatile fatty acids in the feces during subacute rumen acidosis in dairy cows. BMC Vet. Res. 8:237.

Moore, C. L., P. M. Walker, J. R. Winter, M. A. Jones, and J. W Webb. 1989. Zinc methionine supplementation for dairy cows Trans. Ill. St. Acad. Sci. 82:99-108.

NRC. 2001. Nutrient Requirements of Dairy Cattle. 7th rev. ed. ed. Natl. Acad. Sci., Washington, DC

Quast, C., E. Pruesse, P. Yilmaz, J. Gerken, T. Schweer, P. Yarza, J. Peplies, and F. O. Glöckner. 2013. The SILVA ribosomal RNA gene database project: Improved data processing and web-based tools. Nucleic Acids Res. 41(D1):D590-D596.

Rabiee, A. R., I. J. Lean, M. A. Stevenson, and M. T. Socha. 2010. Effects of feeding organic trace minerals on milk production and reproductive performance in lactating dairy cows: A meta-analysis. J. Dairy Sci. 93:4239-4251.

Shanks, O. C., C. A. Kelty, S. Archibeque, M. Jenkins, R. J. Newton, S. L. McLellan, S. M. Huse, and M. L. Sogin. 2011. Community structures of fecal bacteria in cattle from different animal feeding operations. Appl. Environ. Microbiol. 77:2992-3001.

Shao, Y., Z. Lei, J. Yuan, Y. Yang, Y. Guo, and B. Zhang. 2014. Effect of zinc on growth performance, gut morphometry, and cecal microbial community in broilers challenged with Salmonella enterica serovar Typhimurium. J. Microbiol. 52:1002-1011.

Siciliano-Jones, J. L., M. T. Socha, D. J. Tomlinson, and J. M. DeFrain. 2008. Effect of trace mineral source on lactation performance, claw integrity, and fertility of dairy cattle. J. Dairy Sci. 91:1985-1995.

Tomlinson, D. J., C. H. Mulling, and T. M. Fakler. 2004. Invited review: Formation of keratins in the bovine claw: Roles of hormones, minerals, and vitamins in functional claw integrity. J. Dairy Sci 87:797-809

Weiss, W. P., and M. T. Socha. 2005. Dietary manganese for dry and lactating Holstein cows. J. Dairy Sci. 88:2517-2523.

Wells, J. E., M. Kim, J. L. Bono, L. A. Kuehn, and A. K. Benson. 2014 Meat Science and Muscle Biology Symposium: O157:H7, diet, and fecal microbiome in beef cattle. J. Anim. Sci. 92:1345-1355.

Yu, Z., and M. Morrison. 2004. Improved extraction of PCR-quality community DNA from digesta and fecal samples. Biotechniques $36: 808-812$.

Zinicola, M., F. Lima, S. Lima, V. Machado, M. Gomez, D. Döpfer, C. Guard, and R. Bicalho. 2015. Altered microbiomes in bovine digital dermatitis lesions, and the gut as a pathogen reservoir. PLoS One 10:e120504. 